\title{
PERANAN GURU PENDIDIKAN AGAMA ISLAM DALAM PEMBENTUKAN KARAKTER SISWA DI SMP AL KAUTSAR BANDAR LAMPUNG
}

\author{
Sumiyati \\ Universitas Sang Bumi Ruwa Jurai \\ sumiiiyati216@gmail.com
}

\begin{abstract}
Abstrak.
Dalam pengembangan karakter peserta didik di sekolah, guru memiliki posisi yang strategis sebagai pelaku utama. Guru merupakan sosok yang bisa digugu dan ditiru atau menjadi idola bagi peserta didik. Guru bisa menjadi sumber inspirasi dan motivasi peserta didiknya. Sikap dan prilaku seorang guru sangat membekas dalam diri siswa, sehingga ucapan, karakter dan kepribadian guru menjadi cermin siswa. Tujuan dari penelitian ini adalah mengetahui peran guru pendidikan agama Islam dalam pembentukan karakter siswa SMP Al-Kautsar Bandar Lampung. Jenis penelitian ini adalah penelitian kualitatif dengan menggunakan pendekatan deskriptif dimana hasil penelitian disajikan secara deskripsi. Metode pengumpulan data menggunakan observasi, wawancara, dan dokumentasi yang kemudian dianalisis dengan menggunakan reduksi data, penyajian data dan kesimpulan atau verifikasi. Berdasarkan hasil analisis dan temuan pada penelitian ini dapat disimpulkan bahwa guru pendidikan agama Islam telah menjalankan perannya dalam pembentukan karakter siswa namun hasil yang diharapkan belum maksimal karna masih rendahnya minat, semangat dan kesadaran siswa untuk mengamalkan nilai-nilai ajaran Islam yang telah disampaikan oleh guru pendidikan agama Islam.
\end{abstract}

Kata kunci: Peranan Guru, Pembentukan Karakter.

Abstract.

In developing the character of students in schools, teachers have a strategic position as the main actors. The teacher is a figure who can be digested and imitated or become an idol for students. Teachers can be a source of inspiration and motivation for their students. The attitudes and behavior of a teacher make an impression on students, so that the teacher's speech, personality and personality become a mirror of students. The purpose of this study was to see the role of Islamic education teachers in character orders for Al-Kautsar Junior High School students in Bandar Lampung. This type of research is qualitative research using a descriptive approach where the results are presented with descriptions. Methods of using data using observation, interviews, and documentation which are then analyzed using data reduction, data presentation and study or levers. Based on the results of the analysis and the findings of this study, it can be ignored that the Islamic religious education teacher has played its role in ordering the character of students, but the expected results are not optimal because of the low interest, enthusiasm and awareness of students to practice the values of Islamic teachings conveyed by Islamic religious education teachers.

Keywords The Role of the Teacher, Character Building.

\section{PENDAHULUAN}

Pendidikan selain bertujuan untuk tercapainya suatu keberhasilan akademis, hal yang lebih penting adalah bagaimana dapat tercapainya atau terbentuknya suatu karakter yang positif pada diri masing-masing siswa. Dalam hal ini dunia pendidikan harus memberi peran penting dalam pembentukan karakter siswa dalam upaya menyiapkan generasi muda masa depan yang lebih baik.

Guru dituntut untuk menjadi teladan dalam pembentukan karakter siswa. Karena sebaik apapun kurikulum yang ada akan sangat tergantung pada guru. Al Mawardi mengatakan "Keberhasilan pendidikan sebagian besar bergantung pada kualitas guru baik segi penguasaan terhadap materi pelajaran yang akan diajarkan maupun cara penyampaian pelajaran tersebut serta 
kepribadian yang baik, yaitu kepribadian yang terpadu antara ucapan dengan perbuatan secara harmonis". Peran guru tersebut meliputi banyak hal, sebagaimana dikemukakan oleh Adam dan Dekey dalam bukunya Basic Principles of Student teaching, antara lain guru berperan sebagai pengajar, pemimpin kelas, pembimbing, pengatur lingkungan, partisipan, expesitor, perencanaan, supervisor, motovator dan konselor.(Nata, 2001)

Tugas dalam mendidik merupakan rangkaian dari proses belajar-mengajar, memberikan dorongan, memuji, memberi contoh dan membisakan. Kemendiknas (2000) mengindikasikan bahswa tugas utama guru antara lain adalah sebagai berikut: (1) Tugas guru sebagai pengajar (Intruksional). Sebagai pengajar (intruksional), guru bertugas merencanakan progam pengajaran, melaksanakan progam yang telah disusun dan melaksanakan penilaian setelah progam itu dilaksanakan; (2) Tugas guru sebagai pendidik (Edukator). Sebagai pendidik (edukator) guru bertugas mengarahkan peserta didik pada tingkat kedewasaan yang berkepribadian sempurna; (3) Tugas guru sebagai pemimpin (Managerial). Sebagai pemimpin, guru bertugas memimpin dan mengendalikan diri sendiri, peserta didik dan masyarakat yang terkait, menyangkut upaya pengarahan, pengawasan, pengorganisasian, pengontrolan, partisipasi atas progam yang dilakukan.(Darmadi, 2015)

Enco Mulyasa juga mengatakan, guru memiliki peran sebagai "Pendidik, pengajar, pembimbing, pelatih, penasehat, pembaharu, model teladan, pribadi, peneliti, pendorong kreatifitas, pembangkit pandangan, pekerja rutin, pemindah kemah, pembawa cerita, actor, emansipator, evaluator, pengawet dan kulminator".(Mulyasa, 2008)

Betapa pentingnya peran seorang guru dalam membentuk karakter peserta didik juga ditegaskan oleh Athiyah al-Abrasyi bahwa "Guru agama adalah bapak rohani bagi siswa, yaitu yang memberikan santapan jiwa dengan ilmu pendidikan akhlak dan membenarkannya". Selain itu peran penting guru dalam pembentukan karakter juga ditegaskan oleh Abdul Majid dan Diana Nadayani, yang menyatakan bahwa:

Guru adalah pekerjaan mencetak generasi dan membangun umat. Guru adalah salah satu faktor yang mempengaruhi kualitas pendidikan". Para pakar menyatakan bahwa, betapa pun bagusnya kurikulum (official), hasilnya sangat bergantung pada apa yang dilakukan guru di dalam maupun di luar kelas (aktual).(Subianto, 2013)

Guru harus mampu menanamkan nilai-nilai agama kepada setiap peserta didik dengan berbagai cara. Aspek nilai-nilai ajaran Islam yang ditanamkan kepada peserta didik ditinjau dari pola sikap dan perilaku kepada Allah antara lain meliputi aspek nilai-nilai aqidah, ibadah mahdlah, dan akhlak.

Seorang anak dalam mencari nilai-nilai hidup, harus mendapat bimbingan sepenuhnya dari pendidik, karena menurut ajaran Islam, saat anak dilahirkan dalam keadaan lemah dan suci/fitrah, dan alam disekitarnyalah yang akan memberi corak warna terhadap nilai hidup atas pendidikan seorang anak, khususnya pendidikan karakter. Rasulullah SAW bersabda:

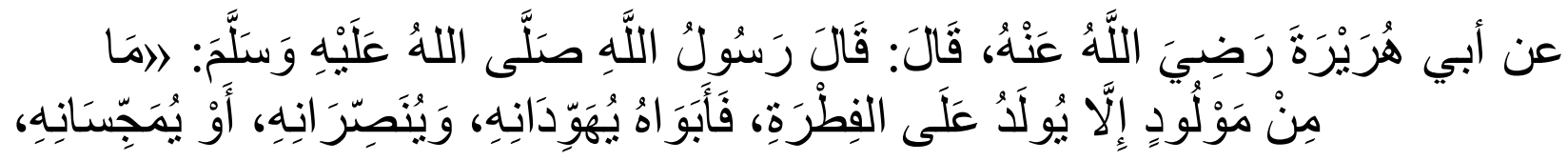

Artinya: "Dari Abu Hurairah, ia berkata, Rasulallah saw bersabda, "Tidaklah seorang anak dilahirkan kecuali dalam keadaan fitrah. Lalu kedua orang tuanyalah yang menjadikan ia Yahudi, Nashrani, dan Majusi”. (HR. Bukhori Muslim).(Al-Mundziri, 2003). 
Karakter merupakan prilaku manusia yang berhubungan dengan Tuhan Yang Maha Esa, diri sendiri, sesama manusia, lingkungan dan kebangsaan yang terwujud dalam pikiran, sikap, perasaan, perkataan dan perbuatan yang berdasarkan norma-norma agama, hukum, tatakrama, budaya dan adat istiadat. Orang yang prilakunya sesuai dengan norma-norma disebut berkarakter mulia.(Gunawan, 2001)

Karakter mulia adalah seorang individu yang memiliki pengetahuan tentang potensi dirinya, yang ditandai dengan nilai-nilai seperti reflektif, percaya diri, rasional, logis, kritis, analitis, kreatif dan inovatif, mandiri, hidup sehat, bertanggung jawab, cinta ilmu, sabar, berhati-hati, rela berkorban, pemberani, dapat dipercaya, jujur, menepati janji, adil, rendah hati, dan nilai-nilai lainnya. Individu juga memiliki kesadaran untuk berbuat yang terbaik dan unggul dan individu yang mampu bertindak sesuai potensi dan kesadarannya tersebut. Pendidikan karakter pada hakikatnya merupakan pengintegrasian antara kecerdasan, kepribadian, dan akhlak mulia.(Johansyah, 2017)

Karakter mulia adalah seorang individu yang memiliki pengetahuan tentang potensi dirinya, yang ditandai dengan nilai-nilai seperti reflektif, percaya diri, rasional, logis, kritis, analitis, kreatif dan inovatif, mandiri, hidup sehat, bertanggung jawab, cinta ilmu, sabar, berhati-hati, rela berkorban, pemberani, dapat dipercaya, jujur, menepati janji, adil, rendah hati, dan nilai-nilai lainnya. Individu juga memiliki kesadaran untuk berbuat yang terbaik dan unggul dan individu yang mampu bertindak sesuai potensi dan kesadarannya tersebut.

Berdasarkan penelitian sebelumnya tentang Hasil penelitian ini menunjukkan bahwa peran guru dalam pendidikan karakter siswa di SMA Negeri 3 Yogyakarta yaitu; (a) sebagi pendidik yaitu, peran yang berkaitan dengan tugas memberikan bantuan dan dorongan terhadap aturanaturan sekolah dan norma hidup dalam keluarga dan masyarak; (b) sebagai teladan yaitu, guru menjadikan dirinya sebagai panutan bagi siswa (c) motivator yaitu, dengan adanya kemampuan guru dalam membangkitkan spirit, etos kerja, dan potensi yang luar biasa dalam diri peserta didik; (d) sebagai pengajar dan pembimbing yaitu, setiap guru harus memberikan pengetahuan, keterampilan pada siswa. Selain itu, peran kepala sekolah dalam pendidikan karakter siswa yaitu sebagai berikut: (a) manajer yaitu, sebagai penentu kebijakan yang mampu mengakomodir seluruh kebutuhan siswa terkait pendidikan karakter; (b) pemimpin yaitu, memberikan petunjuk dan pengawasan, kemampuan mengambil keputusan, dan kemampuan berkomunikasi; (c) mendorong semua guru dan karyawan untuk menjadi model karakter yang baik bagi semua siswa.(Ajmain \& Marzuki, 2019). Selanjutnya penelitian tentang Dari hasil penelitian diperoleh gambaran bahwa sebagian besar sekolah tidak memiliki kebijakan dan administrasi mengenai pendidikan karakter, sebagian besar sekolah yang memiliki lingkungan yang mendukung penyelenggaraan pendidikan karakter, sebagian besar guru tidak memiliki pengetahuan dan sikap yang baik dalam pendidikan karakter, sebagian besar guru tidak memiliki kompetensi yang baik, sebagian besar sekolah telah menggunakan kurikulum dan sebagian besar guru belum menggunakan penilaian yang cocok bagi pendidikan karakter dan sebagian besar masyarakat belum mendukung jalannya pendidikan karakter.(Citra, 2012)

Dalam hal ini peranan guru Pendidikan Agama Islam dalam pembentukan nilai-nilai karakter siswa di SMP Al Kautsar Bandar Lampung seperti yang diungkapkan oleh kepala SMP Al Kautsar Bandar Lampung bahwa "peranan guru Pendidikan Agama Islam secara teori maupun praktek 
dalam menjalankan tugasnya telah berusaha dengan baik dan bertanggung jawab dalam menanamkan nilai-nilai karakter kepada peserta didik, serta dengan menggunakan berbagai macam metode dan media pembelajaran yang ada untuk mendukung tercapainya tujuan pendidikan".

Selain itu penanaman nilai-nilai ajaran Islam pada siswa SMP Al Kautsar Bandar Lampung seperti yang dipaparkan oleh Ibu Nurhayati, S.Ag selaku guru agama di SMP Al Kautsar Secara normatif sudah terlihat pada Kurikulum materi pelajaran agama. Dalam materi tersebut terlihat adanya penekanan adab sopan-santun kepada orang tua dan gurunya, adab sopan-santun kepada tetangga, dan beberapa anjuran untuk menyayangi sesama manusia, beramal, shodaqoh sebagai rasa syukur atas nikmat rezeki yang diberikan oleh Allah serta kepedulian sosial dan semua sikap dan perilaku itu hendaknya dilakukan karena percaya akan adanya Allah yang maha mengasihi dan menyayangi kepada hamba-hambanya yang berbuat kebajikan.

Dengan demikian berdasarkan uraian diatas peneliti tertarik untuk mengambil judul Peranan Guru Pendidikan Agama Islam Dalam Pembentukan Karakter Siswa Di SMP Al Kautsar Bandar Lampung.

\section{METODE PENELITIAN}

Metode yang digunakan dalam penelitian ini adalah jenis penelitian kualitatif dengan menggunakan pendekatan deskriptif dimana hasil penelitian disajikan secara deskripsi. Lokasi penelitian ini adalah di SMP Al-Kautsar Bandar Lampung. Penelitian bertujuan untuk mengetahui peran guru pendidikan agama Islam Dalam Pembentukan Karakter siswa.

Penelitian ini berupaya untuk memusatkan perhatian pada Peranan Guru Pendidikan Agama Islam (PAI) Dalam Pembentukan Karakter Siswa di SMP Al Kautsar Bandar Lampung yang hasilnya akan dijabarkan secara diskriptif analitik. Sumber data yang digunakan dalam penelitian ini menggunakan data primer dan data sekunder. Teknik pengumpulan data yang digunakan adalah observasi, wawancara dan dokumentasi. Teknik analisis data yang digunakan yaitu Data Reduction (Reduksi Data), Data Display ( Penyajian Data), dan Conclusion Drawing ( verification).

\section{HASIL DAN PEMBAHASAN}

Berdasarkan penelitian yang dilakukan bahwa peranan guru pendidikan agama Islam (PAI) dalam pembentukan Karakter siswaa di SMP Al-Kautsar Bandar Lampung adalah sebagai berikut:

\section{Guru PAI Sebagai Pemimpin}

Guru PAI sebagai pemimpin kelas harus mampu menciptakan atmosfer kelas yang ilmiah, agamis dan menyenangkan serta membangun kelas sebagai tempat yang menyenangkan. Guru sebagai pemimpin kelas harus dapat berbagi peran, harus menguasai berbagai informasi dan ilmu pengetahuan, dan dapat menciptakan suasana yang memotivasi siswa dan dapat membangkitkan inovasi, prestasi secara kompetitif serta membina siswa untuk menjadi generasi yang intlek dan inovatif.

Dalam proses pembelajaran guru PAI selalu dapat menguasai kelas, menciptakan suasana kelas yang kondusif dan menyenangkan. Siswa selalu senang menerima pelajaran dengan perasaan nyaman. Guru PAI selalu berusaha mengelola dan membuat suasana belajar yang menyenangkan, guru selalu mengarahkan, membimbing dan memberikan solusi dalam menghadapi kesulitan belajar siswa, sehingga guru PAI menjadi salah satu idola bagi siswa.

Dari hasil wawancara dengan Ummi Tri sunah, tentang peranan guru PAI sebagai pemimpin kelas yaitu "Dalam proses belajar mengajar di kelas diciptakan suasana belajar yang 
aktif. Siswa diberikan kebebasan untuk berinovasi, bertanya, berpendapat dengan suasana yang tetap islami seperti mengawali dan mengahiri kegiatan dengan membaca basmalah, berdo'a, mengaji dan melaksanakan sholat sunnah dan wajib. Mengajukan pendapat dengan cara-cara yang islami dan memberikan sangsi dengan cara-cara yang islami pula.

Dalam kegiatan pembelajaran dibangun persaingan yang sehat untuk memotivasi antar siswa, misalnya siswa yang sudah dapat menghafal hadits atau surat maka berhak memperoleh satu pin bintang yang sudah dipersiapkan oleh guru dan boleh memimpin do'a sebelum pulang sekolah. Sedangkan yang belum dapat menghafal hadits dan surat yang telah ditentukan oleh guru dia mendapat stepel smile yang bertuliskan study hard.

Dalam pembentukan karakter siswa di SMP Al Kautsar guru PAI selalu mengajarkan kepada siswa untuk mengamalkan nilai-nilai ajaran Islam dalam segala aktifitas sehari-hari. Apa yang sudah diketahui hendaknya selalu diamalkan, nilai-nilai ajaran Islam hendaknya selalu mewarnai setiap perkataan dan perbuatan. Dari hasil observasi dan wawancara tersebut terlihat bahwa guru PAI telah menjalankan perannya sebagai pemimpin kelas, dengan menciptakan suasana yang kondusif, memotivasi dan menyenangkan. Guru PAI juga selalu menanamkan nilai-nilai ajaran Islam dan memotivasi siswa agar senang dan semangat dalam belajar dan beribadah.

\section{Guru PAI Sebagai Pendidik}

Sebagai seorang guru PAI selain berperan sebagai pemimpin, guru PA juga berperan sebagai pendidik selain mengajarkan ilmu pengetahuan agama guru pAI juga menanamkan nilai-nilai ajaran Islam agar siswa selalu berkarakter islami dengan mengamalkan nilai-nilai ajaran Islam. Guru PAI selalu membimbing dan membina siswa dalam kegiatan keagamaan seperti memperingati hari-hari besar Islam, sholat dhuha, sholat dzuhur berjamaah, jum'at berinfaq, lomba-lomba keislaman, kegiatan sanggar keagamaan dan kegiatan-kegiatan sosial lainnya.

Upaya pembentukan karakter pada siswa juga dilakukan secara kontinyu pada setiap kesempatan sehingga dapat membentuk karakter yang diharapkan. Setiap mengawali da mengakhiri proses belajar mengajar selalu disampaikan pesan-pesan moral sehingga dapat memotivasi siswa untuk selalu melaksanakan kebaikan.

Guru PAI dalam melaksanakan perannya sebagai pendidik tidak hanya berlangsung di dalam kelas tetapi juga di luar jam-jam pelajaran PAI, seperti pembinaan pada jam ektrakurikuler, pendekatan pada jam istirahat dan pada saat-saat bisa bersama siswa. Misalnya pada jam istirahat pada saat siswa makan diingatkan untuk berdo'a terlebih dahulu, tidak sambil jalan dan berdiri serta menggunakan adab-adab ketika makan. Mengingatkan siswa untuk membaca istighfar ketika berucap dan bersikap yang tidak sesuai dengan tuntunan agama Islam, mengucapkan rasa syukur dengan hamdalah ketika mendapat nikmat dari Allah SWT dan seagainya.

Upaya pembentukan karakter siswa juga dilakukan guru PAI misalnya dengan melaksanakan kegiatam psantren kilat, siraman rohani pada saat sholat dhuha dan sholat dzuhur berjamaah setiap hari. Dari hasil dokumentasi dan wawancara guru PAI telah berperan sebagai pendidik bukan hanya pada jam-jam pelajaran tetapi juga di luar jam pelajaran. Guru PAI dalam membentuk karakter siswa bukan hanya menanamkan ilmu pengetahuan tetapi juga menanamkan nilai-nilai ajaran Islam.

\section{Guru PAI Sebagai Motivator}

Peran guru PAI sebagai motivator telah berjalan dengan baik, dimana para guru PAI selalu bekerjasama dalam membimbing dan memotivasi siswa untuk selalu mengamalkan nilai-nilai ajaran Islam sehingga terbentuk karakter yang diharapkan pada diri masing-masing siswa. 
Misalnya siswa yang sudah khatam membaca Al Qur'an berhak mendapatkan medali dan piagam pada saat acara khataman Al Qur'an yang diselenggarakan guru PAI setiap tahunnya.

Peran guru PAI sebagai motivator dalam upaya pembentukan karakter siswa juga dlakukan dengan memotivasi siswa agar dapat menghafal juz 30 yang dimotivasi dengan adanya kegiatan sanggar tahfizh. Guru PAI juga memotivasi siswa untuk selalu tekun dalam menuntut ilmu dengan mengambil pelajara dari orang-orang terdahulu karena orang yang beriman dan berilmu pengetahuan derajatnya akan ditinggikan oleh Allah SWT. Guru PAI juga selalu mengingatkan siswa bahwa apabila kita senantiasa melaksanakan kebaikan maka kita akan mendapatkan ganjaran pahala yang akan mengantarkan kita kepada kehidupan yang abadi kelak dan kita akan ditempatkan di tempat yang mulia di sisi Allah SWT. Siswa juga dimotivasi untuk melaksanakan sholat berjamaah, mengucapkan salam apabila bertemu dengan sesama muslim, berpakaian sesuai dengan tuntunan agama Islam, membiasakan pola hidup bersih serta selalu mengamalkan ajaran yang diwajibkan dan sunnah-sunnah Rosulullah SAW.

\section{Guru PAI Sebagai Teladan}

Guru PAI juga telah berperan sebagai teladan bagi siswa dimana guru PAI selalu menjadi motor penggerak dan teladan dalam pembentukan karakter siswa yang sesuai dengan ajaran Islam. Keteladanan yang ditunjukkan oleh guru PAI seperti pada saat adzan guru PAI menghentikan segala aktivitas dan mengajak siswa untuk bersama-sama menyimak kumandang adzan yang sedang terdengar, mengajak siswa untuk sholat berjamaah, sama-sama menjaga kebersihan lingkungan sekolah dengan niat karena Allah SWT, berinfaq dan bersodaqoh dengan keikhlasan, menunjukkan sikap dan perkataan yang patut menjadi teladan bagi siswa seperti membiasakan MAGIC WORD seperti kata-kata maaf, tolong, trimakasih, dan menggunakan kalimat-kalimat tasbih, tahmid, tahlil, istighfar, istirja, hamdalah dll sesuai dengan keadaan yang dihadapi. Dalam pembentukan karakter siswa guru PAI juga menggunakan metode pembiasaan dimana guru bersama-sama siswa agar senantiasa terbiasa membantu orang yang membutuhkan bantuan, sholat dhuha setip hari, tadarrus, berdo'a sebelum melakukan sesuatu, mengamalkan puasa-puasa sunnah, rajin berinfaq, menjaga kebersihan, menebarkan salam, bertutur kata yang baik dan sopan, menjaga silaturrahmi, menghargai dan menghormati sesama, selalu disiplin datang dan pulang sekolah sesuai dengan aturan sekolah yang telah ditetapkan.

\section{Guru PAI Sebagai Fasilitator}

Guru PAI di SMP Al Kautsar telah berperan sebagai fasilitator dimana guru PAI selalu berusaha mengadakan dan menyediakan berbagai media pembelajaran seperti membuat buku materi pembelajaran sendiri, buku monitoring untuk kegiatan pembiasaan sebelum proses belajar mengajar dimulai. Menyediakan buku-buku keagamaan seperti buku kisah-kisah teladan buku Iqro', alat-alat peraga seperti miniatur ka'bah, huruf-huruf hijaiyah, CD-CD interaktif yang memuat materi pembelajaran yang model dan suara diperankan langsung oleh siswa dan para guru agama SMP Al Kautsar, pemberian materi pembelajaran dengan menggunakan LCD serta banner-banner yang memuat alat peraga pembelajaran dan pesan-pesan moral lainnya. Dalam proses pembentukan karakter siswa seperti yang diungkapkan oleh ummi Trisunah misalnya dalam membentuk karakter siswa agar taat menjalankan perintah Allah SWT yang salah satunya adalah ketaatan dalam melaksanakan perintah sholat lima waktu, para siswa diberikan tuntunan dan pemahaman tentang pelaksanaan sholat yang benar. Para siswa secara langsung diajak praktek sholat di musholla dengan dibimbing bagaimana bacaan dan gerakan sholat yang benar.

Pada kesempatan lain menurut Ibu Nurhayati, S. Ag dalam pembentukan karakter siswa agar dapat mengenal seni kaligrafi huruf-huruf Al Qur'an para siswa difasilitasi untuk mempelajari seni kaligrafi. Para siswa diajak ke luar kelas menuju aula outbond yang memang 
disediakan oleh Yayasan Al Kautsar sebagai tempat siswa-siswa mulai dari TK sampai SMA untuk mengembangkan dan memperaktekkan langsung tentang materi yang telah disampaikan oleh guru. Dalam memberikan pemahaman tentang bacaan-bacaan surat pendek beserta arti dan isi kandungannya misalnya dalam memberikan pemahaman tentang surat Az Zalzalah menurut abi Amiruddin agar terbentuk karakter siswa yang taat dengan berpedoman pada firman Allah yang terdapat dalam kitab suci Al Qur'an maka siswa diajak masuk kedalam situasi yang menggambarkan tentang kegoncangan yang dahsyat ketika terjadinya hari kiamat. Siswa ditayangkan film tentang kedahsyatan hancurnya bumi pada saat terjadinya hari kiamat misalnya film tentang tsunami.

Dari hasil observasi dan wawancara terlihat bahwa guru PAI dalam menjalankan perannya sebagai fasilitator, yakni menggunakan berbagai strategi dan media yang tepat dalam agar terbentuknya karakter pada diri masing-masing siswa.

\section{Guru PAI Sebagai Evaluator}

Guru PAI juga telah melaksanakan perannya sebagai evaluator, dimana guru PAI selalu mengadakan evaluasi tentang upaya-upaya pembentukan karakter siswa antara lain yaitu dengan cara menfaatkan proses apersepsi pada setiap awal proses belajar mengajar dan post test di ahir pembelajaran, kemudian mengadakan penilaian harian, tengah semester dan ahir semester dengan menggunakan berbagai macam format penilaian yang mencakup aspek skill, attitude dan knowledge. Penilaian yang dilakukan oleh guru PAI SMP Al Kautsar meliputi tentang aspek keterampilan, ilmu pengetahuan dan sikap. Melalui proses pembiasaan selama 45 menit sebelum proses belajar mengajar dimulai seperti evaluasi tentang pemahaman terhadap bacaan surat-surat pendek, hadits-hadits pilihan, do'a-do'a sehari-hari, pelaksanaan sholat lima waktu, pelaksanaan membaca Al Qur'an atau Iqro', ibadah puasa. Guru PAI juga selalu mengevaluasi perkembangan siswa dalam upaya pembentukan karakter yang akan diharapkan dengan panduan buku monitoring kegiatan keagamaan yang disusun oleh team guru PAI SMP Al Kautsar dan pengamatan terhadap perkembangan karakter siswa baik pada jam-jam pelajaran maupun diluar jam pelajaran.

Dari hasil observasi telah nampak bahwa guru PAI telah melaksanakan perannya sebagai evaluator. Guru PAI dalam melaksanakan penilaian mencakup aspek skill atau keterampilan, attitude atau sikap dan knowlege atau aspek ilmu pengetahuan. Dalam mengadakan penilaian guru PAI memberikan penghargaan maupun hukuman yang sesuai dengan ajaran Islam.

\section{Guru PAI Sebagai Pengajar}

Dari hasil wawancara dengan kepala SMP Al Kautsar Ibu Kepala sekolah Dra. Sri Purwaningsih bahwa dari hasil suvervisi yang beliau dilaksanakan setiap bulannya para guru PAI di SMP Al Kautsar telah menjalankan perannya sebagai pengajar dengan membuat perencanaan pembelajaran dan melaksanakan proses belajar mengajar di sekolah. Hasil dokumentasi berupa instrumen suvervisi, ada beberapa hal yang harus dikuasai dan dimiliki oleh setiap guru di SMP Al Kautsar juga menunjukkan bahwa guru PAI telah melakukan perannya sebagai pengajar dengan baik.

Adapun point-point yang telah dikuasai oleh guru PAI SMP Al Kautsar adalah membuat program tahunan, program semester, sylabus, rencana pelaksanaan pembelajaran, kalender pendidikan, membuat agenda pembelajaran, membuat daftar nilai, membuat analisis hasil belajar, membuat analisis kriteria ketuntasan mengajar, membuat analisis pemetaan standar kompetensi dan kompetensi dasar, membuat analisis butir soal dan bank soal. Dalam proses 
pembelajaran apabila materi pelajaran yang memerlukan praktek secara langsung seperti materi sholat, wudhu, mengaji maka gur PAI secara langsung praktek bersama siswa.

Dari hasil observasi bahwa guru PAI di SMP Al Kautsar Bandar Lampung telah melakukan perannya sebagai pengajar dengan membuat dan melaksanakan semua administrasi pembelajaran yang harus dimiliki dan di laksanakan oleh guru pendidikan agama Islam.

\section{Implementasi Peran Guru PAI Dalam Pembentukan Karakter Siswa}

Guru PAI di SMP Al Kautsar telah melakukan berbagai upaya pembentukan karakter siswa Dalam mengoptimalkan pembelajaran pendidikan agama Islam bahkan peran guru agama Islam di SMP Al Kautsar tersebut mendapatkan penghargaan dari Kanwil Departemen Agama Islam Propinsi Lampung sebagai motivator program keagamaan di lingkungan sekolah umum. Peran guru agama Islam itu antara lain seperti:

a. Kegiatan Pendahuluan

Menyiapkan peserta didik, melakukan apersepsi, menyiapkan KD dan Tujuan pembelajaran yang akan dicapai serta menyampaikan cakupan materi dan penjelasan uraian kegiatan sesuai sylabus/kesiapan bahan ajar.

b. Kegiatan Inti Pembelajaran

1) Eksplorasi

Melibatkan siswa dalam mencapai informasi dan belajar dari aneka sumber dengan menerapkan prinsip alam takambang jadi guru. Menggunakan beragam pendekatan pembelajaran media dan sumber belajar lainnya. Memfasilitasi terjadinya interaksi antara siswa dengan siswa, siswa dengan guru, lingkungan dan sumber belajar lainnya. Melibatkan siswa secara aktif dalam berbagai kegiatan pembelajaran. Memfasilitasi siswa dalam melakukan praktek.

2). Elaborasi

Membiasakan siswa siswa membaca dan menulis yang beragam melalui tugas tertentu yang bermakna. Memfasilitasi siswa untuk melakukan pemberian tugas, diskusi dan lain-lain untuk memunculkan gagasan baru secara lisan maupun tertulis. Memberikan kesenpatan untuk berfikir, menganalisis menyelesaikan masalah dan bertindak yang benar tanpa rasa takut. Memfasilitasi siswa dalam pembelajaran kooperatif dan kolaboratif. Memfasilitasi siswa berkompetisi secara sehat untuk meningkatkan prestasi belajar.

\section{3). Konfirmasi}

Memberikan umpan balik positif dan penguatan dalam bentuk reward dan punishman, memberikan konfirmasi terhadap hasil eksplorasi dan elaborasi siswa melalui berbagai sumber. Memfasilitasi siswa melakukan refleksi untuk memperoleh pengalaman belajar yang telah dilakukan. Berfungsi sebagai nara sumber dan fasilitator dalam menjawab pertanyaan siswa yang menghadapi kesulitan, memberikan motivasi kepada siswa.

4). Penutup

Dalam kegiatan penutup dalam proses pembelajaran guru PAI membuat rangkuman/kesimpulan tentang materi yang telah disampaikan, melakukan penilaian dan refleksi terhadap kegiatan pembelajaran yang telah dilakukan, memberikan umpan balik terhadap proses hasil pembelajaran, memberikan tugas terstruktur dan kegiatan mandiri tidak terstruktur, menyampaikan rencana pembelajaran pada pertemuan berikutnya. 
Integrasi ajaran Islam dalam kegiatan diluar jam pelajaran juga dilakukan oleh guru PAI seperti kegiatan jum'at berinfaq untuk membentuk karakter siswa terbiasa bersodaqoh, membantu sesama dan memupuk rasa peduli orang-orang yang membutuhkan bantuan serta digunakan untuk kegiatan keagamaan dan kegiatan sosial. Kegiatan psantren kilat yang bertujan agar peserta didik menjadi manusia yang beriman dan bertaqwa kepada Tuhan yang Maha Esa, berakhlak mulia,sehat, berilmu, cakap, kreatif dan menjadi warga negara yangdemokratis serta bertanggung jawab. Peserta didik dapat meningkatkan pemahaman dan penghayatan terhadap rukun iman, kesempurnaan sifat-sifat Allah, dapat melaksanakan rukun islam sesuai dengan syari'at Islam, dapat melaksakan shalat dengan benar, dapat berdzikir dan berdo'a dengan baik, dapat membaca Al-Qur'an dengan baik dan benar, dapat memiliki akhlakul karimah kepada Allah, ibu-bapak, guru, teman dan lingkungannya. Kegiatan pesantren kilat ini dilaksanakan pada saat awal tahun ajaran baru. Kegiatan sholat dhuha yang dilaksanakan setiap pagi, Da'i, partisifasi dalam pelaksanaan qurban, Zakat Infaq dan shodaqoh serta kegiatan-kegiatan keagamaan lainnya yang terprogram dalam program keagamaan SMP Al Kautsar.

\section{KESIMPULAN}

Berdasarkan hasil analisis dan temuan pada penelitian ini dapat disimpulkan bahwa guru pendidikan agama Islam telah menjalankan perannya dalam pembentukan karakter siswa namun hasil yang diharapkan belum maksimal karna masih rendahnya minat, semangat dan kesadaran siswa untuk mengamalkan nilai-nilai ajaran Islam yang telah disampaikan oleh guru pendidikan agama Islam. Peranan guru Pendidikan Agama Islam di SMP Al-Kautsar Bandar Lampung yaitu guru sebagai pemimpin, guru sebagai pendidik, guru sebagai motivator, guru sebagai teladan, guru sebagai fasilitator, guru sebagai evaluator, guru sebagai pengajar.

\section{DAFTAR PUSTAKA}

Ajmain, A., \& Marzuki, M. (2019). Peran Guru Dan Kepala Sekolah Dalam Pendidikan Karakter Siswa Di Sma Negeri 3 Yogyakarta. Socia: Jurnal Ilmu-Ilmu Sosial, 16(1), 109-123. Https://Doi.Org/10.21831/Socia.V16i1.27655

Al-Mundziri, I. (2003). Ringkasan Shahih Muslim.Jakarta: Pustaka Imani.

Citra, Y. (2012). "Pelaksanaan Pendidikan Karakter Dalam Pembelajaran". Jurnal Ilmiah Pendidikan Khusus. Vol 1. No. 1

Darmadi, H. (2015). Tugas, Peran, Kompetensi, Dan Tanggung Jawab Menjadi Guru Profesional. 13(2), 14.

Gunawan, H. (2001). Pendidikan Karakter, Konsep Dan Implementasi. Jakarta: Alfabeta.

Johansyah, J. (2017). Pendidikan Karakter Dalam Islam; Kajian Dari Aspek Metodologis. Jurnal Ilmiah Islam Futura, 11(1), 85. Https://Doi.Org/10.22373/Jiif.V11i1.63

Mulyasa, E. (2008). Menjadi Guru Professional Meningkatkan Pembelajaran Kreatif Dan Menyenangkan. Bandung: Remaja Rosdakarya. 
Seminar Nasional Penelitian dan Pengabdian kepada Masyarakat Universitas Sang Bumi Ruwa Jurai Tahun 2020

Nata, A. (2001). Pemikiran Para Tokoh Pendidikan Islam, Kajian Filsafat Pendidikan Islam. Jakarta: Raja Grafindo Persada.

Subianto, J. (2013). Peran Keluarga, Sekolah, Dan Masyarakat Dalam Pembentukan Karakter Berkualitas. Edukasia: Jurnal Penelitian Pendidikan Islam, 8(2). Https://Doi.Org/10.21043/Edukasia.V8i2.757 